\title{
On acquiring a socially transmitted discovery (STD) in Berlin-and Paris, and Prague
}

\section{David P Stevens}

The improvement of healthcare quality and patient safety is at its heart a social act. I am particularly aware of this each year when I attend the International Forum on Quality and Safety in Health Care. In March 2009 in Berlin, I spent one of the most pleasurable evenings I can remember in a restaurant with colleagues from the UK, Sweden, Spain, Australia, Netherlands, Italy and the USA — a group with whom I meet annually at the International Forum. We enjoyed a similar evening in Paris last year, and in Prague the year before that. I am inevitably the beneficiary of the learning that comes from such a diverse and expert international group. As I reflect on these gatherings, I am reminded that I am the beneficiary of many Socially Transmitted Discoveries (STDs) that are highlights of the annual Forum.

\section{STDS CAN BE PASSED INFORMALLY ACROSS NATIONAL BORDERS}

I live in the USA. We Americans have a reputation for being quick to give advice. Fortunately, the USA now has national political leadership that counsels listening. The US healthcare system is a troubled enterprise, ${ }^{1}$ so we have a lot of listening to do. Granted, American medicine generally provides complex and valuable healthcare. Yet US healthcare per capita costs are about twice that of the next most costly system in developed countries, and its health outcomes are some of the worst. ${ }^{2}$ So, there is plenty of room for improvement. In this regard, Don Berwick ${ }^{3}$ taught me early in my improvement career that diffusion of innovation happens more quickly when we share and make use of the really good ideas that we learn from each other. ${ }^{4}$ Attendees from over 60 countries gathered in Berlin. Hence, the considerable value-in this American's opinion_of an American listening to the

Correspondence to: Dr David P Stevens, Adjunct Professor and Director, Quality Literature Program, Dartmouth Institute for Health Policy and Clinical

Practice, 30 Lafayette Street, Lebanon, NH 03766, USA; david.p.stevens@dartmouth.edu many knowledgeable colleagues who attend the International Forum each year.

\section{PLENARY AND POSTER SESSIONS, AND OTHER LEARNING SETTINGS}

But the formal parts of the Forum are also wonderful examples of colleagues who have reflected carefully on what they can teach the rest of us. For example, I would go anywhere to spend an hour learning from Trisha Greenhalgh, one of last year's plenary speakers. So, the hour spent listening to her in Berlin was absolutely memorable. You can see and hear her talk online at the Forum Site. ${ }^{5}$ Other plenary presentations are there as well. You will see what I mean about innovation and learning.

In addition to the plenary sessions, I also benefit generously from the many excellent original posters ${ }^{6}$ and breakout sessions. But I confess the real value for me in a meeting like this is the social interaction where I can learn, question and discuss. Restaurants are certainly excellent venues for learning, but there is much to learn in chance encounters with colleagues in the hallways and coffee and tea breaks. This is where STDs abound. Truth be told, I have a colleague from Cleveland who confesses that his principal strategy for attending most large meetings like the Forum is to stake out a space at coffee and tea breaks, and then wait for colleagues to arrive and catch up with what has transpired in their institutions over the previous year.

\section{INNOVATE TO SAVE MEETING COSTS}

The Forum is, of necessity-like most large international conferences-expensive to host, so the BMJ and IHI must levy a sufficient attendance fee to meet these costs. It also costs a lot for attendees to travel to the meeting. I have learnt some effective cost-saving innovations over the years. For example, I know of many colleagues who always submit their most recent work in well-crafted posters. If they have been accepted for the Program, they take them to their managers and/or department leaders, and show them what they are doing to share their local success with others. Institutional leaders often are willing to contribute to support attending the Forum when such attendance adds to the good reputation of the institution. It often requires a deft negotiation, but it is the principal way that many delegates are able to raise funds to attend.

So, please go to the Forum website to see examples of successful abstracts from Berlin. Pick several that you think are particularly well presented. They provide opportunities to learn presentation strategies that you can use to present your own original work. The $\mathrm{QIR}^{7}$ and SQUIRE Publication Guidelines ${ }^{8}$ will also be helpful. They are intended for scholarly publications, but they can be adapted to presentation of original improvement work in abstract and poster formats as well.

Here is another STD from last year. The Jonkoping County Council, Sweden, a particularly innovative healthcare system, is dealing with very difficult financial times like we all are. They are so good at healthcare quality improvement that they generally send dozens of improvement professionals to the Forum. In 2009, to save transportation costs, they chartered a motor coach, and all attendees travelled from Jonkoping County to Berlin together. I am told that, while en route, they inescapably spent countless hours working and learning from each other. And think of the krona they did not spend and the carbon they did not release into the atmosphere.

\section{AN EDUCATIONAL INNOVATION: THE STUDENT FORUM}

Finally, health profession students have unique opportunities for reducing their costs of attendance while taking advantage of learning opportunities that are specially targeted to their interests and professional level. There is now a Student Forum-actually a Forum within a Forum-organised by an international group of visionary educational leaders that include Michael Bergstrom and Jill Duncan. ${ }^{9}$ Students can benefit from learner-focused strategies, many of which are actually student-organised. Participants in the Student Forum have the opportunity to apply for scholarships to attend the larger Forum.

\section{INTERNATIONAL FORUM IN NICE}

As a confirmed introvert, it always surprises me how much I enjoy the 
Socially Transmitted Discoveries that I acquire at the annual International Forum for Quality and Safety in Health Care. I anticipate that the 2010 Forum in Nice will be no exception. ${ }^{10}$ I hope to see you there.

Acknowledgements: In the spirit of transparency, the author shamelessly "borrowed" the idea for the title of this editorial from his friend, Dr Iris Litt- then the Editorin-Chief of The Journal of Adolescent Health-while discussing writing and editing in a restaurant in San Diego, California. ${ }^{11}$

Competing interests: DPS is Editor-in-Chief of Quality and Safety in Health Care, which is published by the BMJ Group. BMJ is a co-owner of the International Forum and stands to benefit from its success. Moreover, every Forum attendee receives a subscription to OSHC as part of their full registration, so QSHC in this sense also stands to benefit from the Forum's success.

Qual Saf Health Care 2009;18:242-243.

doi:10.1136/qshc.2009.034983

\section{REFERENCES}

1. Davis K. Uninsured in America: problems and possible solutions. BMJ 2007;334:346-8.

2. Davis K, Schoen C, Schoenbaum SC, et al. Mirror, mirror on the wall: an international update on the comparative performance of American Health Care. Commonwealth Fund (May 2007).

3. Berwick DM. Disseminating innovations in health care. JAMA 2003;289:1969-75.

4. Rogers EM. Diffusion of innovations. 5th edn. New York: Free Press, 2003:551:22.

5. Greenhalgh T. Transforming whole systems: in search of theory and method. http://axisto.com/ webcasting/bmj/berlin-2009/plenary-3/index.htm (accessed 5 July 2009).

6. International Forum on Quality and Safety in Health Care website. http://internationalforum.bmi.com/ 2010-forum/international-forum-posters (accessed 5 July 2009).

7. Moss F, Thomson RG. A new structure for quality improvement reports. Qual Health Care 1999;8:76

8. Davidoff F, Batalden P, Stevens D, et al. Publication guidelines for quality improvement in health care: evolution of the SQUIRE project. Oual Saf Health Care 2008;17(1 Suppl):i3-9.

9. International Forum on Quality and Safety in Health Care website. http://internationalforum.bmj.com/2010-forum/ 2009-student-experience (accessed 5 July 2009).

10. International Forum on Quality and Safety in Health Care website. http://internationalforum.bmj.com/ (accessed 29 Jun 2009).

11. Litt IF. "It couldn't happen to me": contracting an STD in Paris. J Adolesc Health 1997:20:1.

\section{BMJ Careers Fair}

\section{2-3 October 2009, Business Design Centre, London, UK}

9-10 October 2009, Thinktank, Birmingham, UK

$\mathrm{BMJ}$ is the largest organiser of medical recruitment fairs across the UK. This year we are organising two careers fairs, in partnership with the London Deanery on 2-3 October in London, and the West Midlands Deanery on 9-10 October in Birmingham.

Whatever your grade or specialty there is a careers fair for you. You can:

- attend seminars on topics such as CV writing, interview skills, planning your career and working abroad

- visit exhibition stands to get careers advice, find a new job, identify alternative career pathways

It's free to attend the exhibition if you register online in advance. There is a small fee for attending our seminar programme.

Register online today at www.careersfair.bmj.com 